\title{
The influence of the European paediatric regulation on marketing authorisation of orphan drugs for children
}

Annemarie Rosan Kreeftmeijer-Vegter ${ }^{1,2^{*}}$, Anthonius de Boer ${ }^{1}$, Roselinda $\mathrm{H}$ van der Vlugt-Meijer ${ }^{2}$ and Peter J de Vries ${ }^{2,3}$

\begin{abstract}
Background: Drug development for rare diseases is challenging, especially when these orphan drugs (OD) are intended for children. In 2007 the EU Paediatric Drug Regulation was enacted to improve the development of high quality and ethically researched medicines for children through the establishment of Paediatric Investigation Plans (PIPs). The effect of the EU Paediatric Drug Regulation on the marketing authorisation (MA) of drugs for children with rare diseases was studied.
\end{abstract}

Methods: Data on all designated orphan drugs, their indication, MA, PIPs and indication group (adult or child) were obtained from the European Medicines Agency (EMA). The outcome and duration of the process from orphan drug designation (ODD) to MA, was compared, per indication, by age group. The effect of the Paediatric Drug Regulation, implemented in 2007, on the application process was assessed with survival analysis.

Results: Eighty-one orphan drugs obtained MA since 2000 and half are authorised for (a subgroup of) children; another 34 are currently undergoing further investigations in children through agreed PIPs. The Paediatric Drug Regulation did not significantly increase the number of ODDs with potential paediatric indications (58\% before vs $64 \%$ after 2007 of ODDs, $p=0.1$ ) and did not lead to more MAs for ODs with paediatric indications (60\% vs 43\%, $p=0.22$ ). ODs authorised after 2007 had a longer time to MA than those authorised before 2007 (Hazard ratio (95\% Cl) 2.80 (1.84-4.28), $\mathrm{p}<0.001)$; potential paediatric use did not influence the time to MA (Hazard ratio (95\% Cl) 1.14 (0.77-1.70), $p=0.52)$.

Conclusions: The EU Paediatric Drug Regulation had a minor impact on development and availability of ODs for children, was associated with a longer time to MA, but ensured the further paediatric development of drugs still off-label to children. The impact of the Paediatric Drug Regulation on research quantity and quality in children through PIPs is not yet clear.

Keywords: European paediatric drug regulation, Orphan drug development, Paediatric use, Paediatric investigation plan, Rare diseases

\footnotetext{
* Correspondence: A.R.Kreeftmeijer-Vegter@uu.nl

${ }^{1}$ Utrecht Institute for Pharmaceutical Sciences, Division of

Pharmacoepidemiology and Clinical Pharmacology, Utrecht University,

P.O. Box 80 082, 3508 TB Utrecht, The Netherlands

${ }^{2}$ ACE Pharmaceuticals BV, Schepenveld 41, 3891 ZK Zeewolde,

The Netherlands

Full list of author information is available at the end of the article
} 


\section{Introduction}

Rare diseases are defined as life-threatening or chronically debilitating conditions with such a low prevalence that special combined efforts are needed to ensure adequate medical care. As a guide, a prevalence of less than 5 per 10,000 citizens in the European Union (EU) is considered low [1]. A low prevalence still equals to approximately 250,000 patients in the Community for diseases near the cut-off point. Much rarer diseases only affect a few dozen patients in the whole EU. There are between 5000 and 8000 rare diseases identified so far, affecting an estimated 30 million EU citizens [2]. Over $80 \%$ of rare diseases have a genetic background, with the great majority being single-gene defects, although multifactorial and chromosomal defects exist. Other non-genetic rare diseases are due to degenerative and proliferative causes, infectious diseases, treatment-related toxicities, alimentary deficiencies, rare poisonings and injuries $[2,3]$. Rare diseases can occur at any age but approximately half of these have their onset at birth or during childhood [4].

Drugs for rare diseases are classified as orphan drugs (ODs). Developing ODs is very challenging. This is mainly due to the various factors that limit clinical studies such as the small number of patients, the heterogeneous and scattered populations, ethical issues (i.e. the use of placebo), lack of validated biomarkers and endpoints, poor diagnostics and limited clinical expertise [5], but also by the lack of return of investment in the small target population [6]. To stimulate research, development and placing on the market of ODs, in 2000, incentives were put in place for drug developers, such as a ten-year marketing exclusivity, access to centralised authorisation procedures and fee reductions for regulatory activities (such as protocol assistance, MA applications and inspections) by the European Medicines Agency (EMA) [6]. Another mechanism that may boost the discovery and development of ODs is "repurposing". This refers to the exploitation of known drugs for new indications [7]. Repurposing receives attention in both the United States and Europe, although differences exist between both continents with respect to policies for repurposing of medicinal products [8]. Several initiatives have been created to identify possible targets for drug repositioning [7]. One of them is the US Food and Drug Administration (FDA) Rare Diseases Repurposing Database to encourage repurposing for rare diseases [9]. There are many examples of ODs that were successfully developed from repurposed drugs $[10,11]$.

The development of drugs for children with rare diseases poses even more challenges than it does for adults. The biology of the growing child, its changing physiology and psychology are much different from adults and requires research that is dedicated to children [12]. Such research is confronted by technical difficulties and legal and ethical constraints. As a consequence, there is little or no investment in research and development of drugs for the paediatric population. More than half of medicines used for children were never or incompletely studied in this population; their use in children is either unlicensed or off label, i.e. out of the scope of the drug's authorised label for age, route of administration, dose frequency, formulation or indication [13]. Use of unlicensed drugs or off-label use is especially common for children with rare diseases and is potentially inefficacious and hazardous [14].

The European Regulation (EC) No 1901/ 2006, hereinafter referred to as the 'Paediatric Drug Regulation' [1] came into force on 26 January 2007 with the objective to improve the health of European children by facilitating the development, accessibility and safe use of new drugs for children aged 0 to 17 years, through clinical studies. These objectives should be achieved without subjecting children to unnecessary clinical trials and without delaying the authorisation for other age populations. This regulation obliges applicants to submit study results to the EMA for each new medicine, new indication, new route of administration or new formulation, according to an agreed Paediatric Investigation Plan (PIP). This PIP describes the planned paediatric studies and their timelines. It should ideally cover all age groups from birth to adolescence. Paediatric studies may be (partially) 'waived' if studies are not feasible, appropriate or safe for (a subset of) the paediatric population or 'deferred' if it is appropriate to conduct studies in adults prior to initiating studies in children or if studies in children will last longer than studies in adults. The PIP should also describe the need for the development of age-appropriate formulations and/or additional non-clinical information (such as developmental toxicity studies in juvenile animal). When the PIP is completed and all requirements are met, applicants are rewarded with a six month extension of patent protection. Off-patent products developed exclusively for use in children are granted eight year data- and ten year market exclusivity for the paediatric indication (the Paediatric Use Marketing Authorisation (PUMA)). ODs are rewarded with two additional years of market exclusivity. The Paediatric Drug Regulation was introduced in stages (see Table 1) distinguishing new medicinal products from already authorised medicinal products.

The implementation of the Paediatric Drug Regulation has paid off for non-orphan medicinal products. Five years after its implementation, more medicines have become available for children and more research has been conducted in children [15]. Over 600 PIPs have been agreed upon and $30 \%$ of those PIPs include studies with neonates, the most neglected group. In addition, more paediatric clinical trials were conducted and the 
Table 1 Implementation phases of the Paediatric Drug Regulation (EC) No 1901/2006

\begin{tabular}{llll}
\hline Category & Application & Jurisdiction & Implementation \\
\hline Off-patent medicine & MA for a paediatric use & Article 30 & 26 July 2007 \\
New medicine & MA that includes a paediatric indication & Article 7 & 26 July 2008 \\
On-patent medicine & To include a paediatric indication in an existing MA* & Article 8 & 26 January 2009 \\
\hline
\end{tabular}

*New indications, pharmaceutical forms and/ or routes of administration which are protected by a supplementary protection certificate or by a patent which qualifies for the granting of a supplementary protection certificate.

All three categories need to comply with the requirements of Article 7: application for MA should include the results of all studies conducted in compliance with an agreed PIP or a decision of the EMA granting a (partial) waiver or deferral [1].

proportion of clinical trials including children increased over the last 6 years, to approximately 10\% [15].

For ODs, the impact of the Paediatric Drug Regulation has not been studied. In this manuscript, we describe the drug application process from orphan drug designation (ODD) to marketing authorisation (MA) and analyse the effect of the Paediatric Drug Regulation on the success rate and time course of obtaining MA.

\section{Methods}

\section{Orphan drug designations and marketing authorisations}

The EMA kindly provided us with a list of all ODDs from 2000 until December 2012 with designation date and number, indication and age category for which the OD is intended (children and/or adults, i.e. potential paediatric use or not). Designations are issued for treatment indications so that drugs with more than one indication occur more than once in this list. Of all ODDs that obtained MA, the European Public Assessment Reports (EPARs) and the product information (Summary of Product Characteristics [SmPC]) available at the EMA website (www.ema.europa.eu) were studied. The following information was extracted: authorisation date, approval conditions (i.e. conditional approval or under exceptional circumstances), indication and age category (children, adults or both) for which the product was authorised. All authorised ODs were cross referenced with the Community register (available at http://ec.europa.eu/health/documents/ community-register/html/index_en.htm) of both ODs and drugs for human use to determine whether the authorised products still benefited from an orphan status or not.

\section{Paediatric investigation plans}

Of all authorised ODs, submitted PIPs including waivers, deferral agreements as well as description and timelines of the required studies (clinical, non-clinical and formulations) were extracted from the EMA website. As a rule, a PIP has to include all subsets of the paediatric population, but waivers for the entire paediatric population (full waivers) or for certain age groups (partial waivers) are granted when one of the following conditions are met: the condition only occurs in the adult population; clinical studies cannot be expected to be of significant therapeutic benefit or are not feasible; the product is considered unsafe or ineffective in children. Full waivers can be granted for classes of medicinal products ('class waivers') or for specific medicinal products ('product specific waiver').

In case of a deferral, the initiation or completion of paediatric studies described in the PIP is postponed until after MA for adults [1].

\section{Time course to marketing authorisation}

The influence of the Paediatric Drug Regulation on the time course of obtaining MA after ODD was analysed using SPSS software version 22.0 (IBM Corp, Armonk, NY, USA). Chi-square was used for subgroup analyses and Cox proportional hazards models were used to examine the impact of potential paediatric use (intended for children yes/no) and approval after or before 2007 (the year in which the Paediatric Drug Regulation was introduced) on time to MA for a designated orphan indication. In order to analyse these effects, the database was restructured from a list of drugs with children and adult indications as separate variables to a table with drug- indication- age combinations. A drug with multiple indications for both children and adults can thus appear more than once in this table. ODD after or before 2007 was entered as separate variable. Time to event was computed as the time elapsed between ODD and MA for every drug-indication-age combination. Since a correlation can be assumed between obtaining authorisation for a paediatric indication and an adult indication for the same medicinal compound, the analysis was also repeated for drugs irrespective of indication by age. When designated orphan products were not authorised yet, the case was censored at the date of analysis.

The effect of repurposing could only be analysed for products with MA using the definition as described by Norman (2013) [10]. This variable was not available for drugs without MA (censored cases). Therefore this variable was not analysed with survival analysis but with General Linear Model (GLM) only. The mean time from ODD to MA was also calculated using the GLM procedure with the following covariates: after/before 2007 and paediatric indication (yes/no).

Differences were taken as significant at $P<0.05$. 


\section{Results}

Orphan drug designations and marketing authorisations From the implementation of the OD Regulation in 2000 until December 2012, 1088 ODDs were granted, 670 (62\%) were intended for children (either exclusively for children $(\mathrm{n}=161)$ or for both children and adults $(\mathrm{n}=509))$ and $418(38 \%)$ were for adults only (Figure 1$)$. As of November 2013, 81 of all granted ODDs had obtained MA. Sixty-five of these were identified as having a potential paediatric use at the time of ODD. Forty of these have indeed become available for children ('onlabel'); 25 potential paediatric products were still off label for children at the time of MA and 16 products were for adults only.

Of the 40 on-label paediatric ODs, 16 are currently under further development for a subset of the paediatric population. The PIP details of these ODs are specified in Table 2.

Of the 25 ODs that are authorised for adults but still off label for children, fifteen products are currently undergoing further development for use in children (Table 3), while the remaining ten are not. Two of those were granted a product specific waiver because the medicinal product did not represent a significant therapeutic benefit over existing treatment for paediatric patients while the remaining eight products did not have a PIP (see below for further details).

For the sixteen ODs for adults, four class waivers were granted for the following conditions: multiple myeloma $(\mathrm{n}=2)$, myelofibrosis $(\mathrm{n}=1)$ and chronic lymphocytic leukaemia $(n=1)$. Five product specific waivers were granted because the condition only occurs in the adult population $(\mathrm{n}=3)$, because the medicinal product did not represent a significant therapeutic benefit over existing treatment for paediatric patients $(n=1)$ or because the product was likely to be unsafe in the paediatric population $(n=1)$. For four products, no PIP was found. One of these was authorised after 2007 but before the implementation of article 8 (in January 2009). Noteworthy is the fact that the potential indication of three products was initially considered for 'adults only' at time of ODD, but these products are currently undergoing paediatric investigations, meaning that they are considered to be of potential paediatric use after all (Table 4).

\section{Paediatric investigation plans}

For 36 authorised ODs no decision or information about a PIP was found. For the majority of the products a PIP was not required because approval was granted before the Paediatric Drug Regulation came into force $(n=19)$ or because application for MA was submitted before the implementation of article $7(n=4)$ or article $8(n=1)$. Unless the applicant files for extension or variation of the initial MA, these medicinal products are likely to remain off label to children. The remaining 12 products without a PIP were developed for (a subgroup of) children.

For 34 authorised ODs, the PIP was required to include development and testing of an age appropriate formulation or conducting non-clinical and clinical studies.

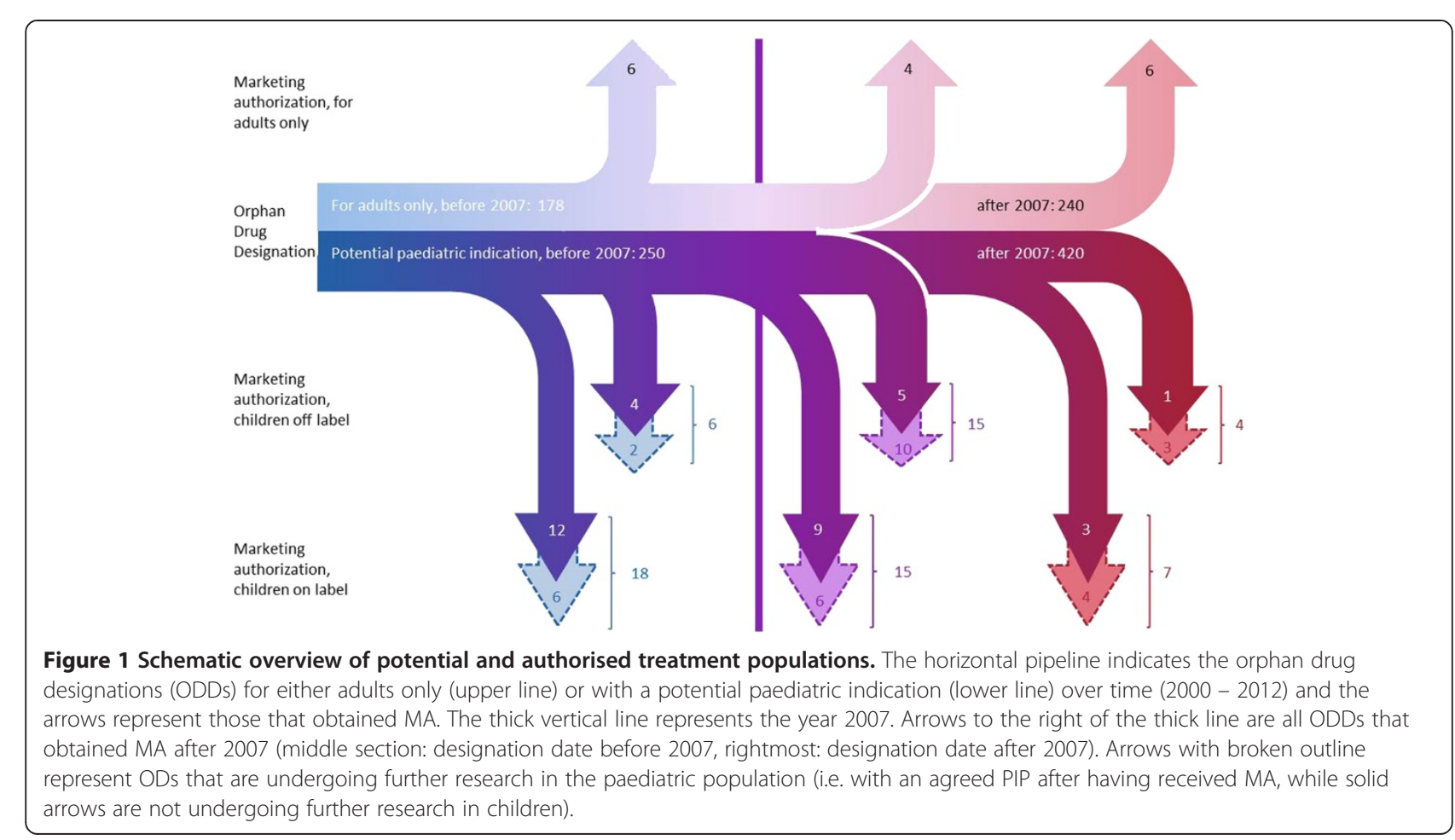


Table 2 PIP details of ODs that are authorised for use in children

\begin{tabular}{|c|c|c|c|c|c|c|}
\hline \multirow{2}{*}{$\begin{array}{l}\text { Medicine name } \\
\text { (active substance) }\end{array}$} & \multicolumn{2}{|c|}{ Paediatric use } & \multicolumn{4}{|c|}{ Paediatric investigation plan } \\
\hline & $\begin{array}{l}\text { Potential } \\
\text { paediatric* }\end{array}$ & $\begin{array}{l}\text { On } \\
\text { labelt }\end{array}$ & Decision $\neq$ & Condition and age covered by waiver & Ground for waiver & $\begin{array}{l}\text { Expected date of } \\
\text { completion } \S\end{array}$ \\
\hline Elaprase (idursulfase) & Yes & All & PW & $\begin{array}{l}\text { Mucopolysaccharidosis II (Hunter syndrome) } \\
\text { (Girls birth to }<18 \mathrm{y} \text { ) }\end{array}$ & $\begin{array}{l}\text { Condition does not occur in the } \\
\text { specified paediatric subset }\end{array}$ & December 2015 \\
\hline Exjadeף (deferasirox) & Yes & 2 & PW & $\begin{array}{l}\text { Chronic iron overload requiring chelation therapy } \\
\text { (birth to }<2 \text { years) }\end{array}$ & $\begin{array}{l}\text { No significant therapeutic } \\
\text { benefit }\end{array}$ & June 2015 \\
\hline \multirow[t]{3}{*}{ Glivec* (imatinib) } & \multirow[t]{3}{*}{ Yes } & \multirow[t]{3}{*}{1} & \multirow[t]{3}{*}{ PW } & $\begin{array}{l}\text { Pulmonary arterial hypertension (PAH) } \\
\text { (birth to }<6 \text { months) }\end{array}$ & Likely ineffective & \multirow[t]{3}{*}{ May 2013: PIP cor } \\
\hline & & & & $\begin{array}{l}\text { Philadelphia chromosome (BCR-ABL translocation) - } \\
\text { positive chronic myeloid leukaemia (birth to }<18 \text { years) }\end{array}$ & $\begin{array}{l}\text { No significant therapeutic } \\
\text { benefit }\end{array}$ & \\
\hline & & & & $\begin{array}{l}\text { Treatment of Philadelphia chromosome (BCR-ABL } \\
\text { translocation) - positive acute lymphoblastic } \\
\text { leukaemia (birth to }<1 \text { year). }\end{array}$ & $\begin{array}{l}\text { Condition does not occur in the } \\
\text { specified paediatric subset }\end{array}$ & \\
\hline \multirow[t]{2}{*}{ Ilaris (canakinumab) } & \multirow[t]{2}{*}{ Yes } & \multirow[t]{2}{*}{2} & \multirow[t]{2}{*}{ PW } & Juvenile idiopathic arthritis (birth to $<24$ months) & $\begin{array}{l}\text { Condition does not occur in the } \\
\text { specified paediatric subset and } \\
\text { no significant therapeutic benefit }\end{array}$ & \multirow[t]{2}{*}{ June 2015} \\
\hline & & & & $\begin{array}{l}\text { Cryopyrin Associated Periodic Syndromes } \\
\text { (CAPS) including: FCAS, FCU, MWS, NOMID } \\
\text { and CINCA* (birth to }<28 \text { days) }\end{array}$ & $\begin{array}{l}\text { No significant therapeutic } \\
\text { benefit }\end{array}$ & \\
\hline Inovelon (rufinamide) & Yes & 4 & PW & $\begin{array}{l}\text { Lennox-Gastaut syndrome (birth to }<12 \\
\text { months and from } 4 \text { to }<18 \text { years) }\end{array}$ & $\begin{array}{l}\text { Condition does not occur in the } \\
\text { specified paediatric subset and } \\
\text { no significant therapeutic benefit }\end{array}$ & September 2017 \\
\hline $\begin{array}{l}\text { Kuvan (sapropterin } \\
\text { dihydrochloride) }\end{array}$ & Yes & 4 & PW & Hyperphenylalaninemia ( 4 to < 18 years) & $\begin{array}{l}\text { No significant therapeutic } \\
\text { benefit }\end{array}$ & January 2014 \\
\hline Mozobil (Plerixafor) & Yes & All & PW & $\begin{array}{l}\text { Myelosuppression caused by chemotherapy to } \\
\text { treat malignant disorders, which requires an } \\
\text { autologous haematopoietic stem cell transplant } \\
\text { (birth to }<12 \text { months ) }\end{array}$ & $\begin{array}{l}\text { No significant therapeutic } \\
\text { benefit }\end{array}$ & June 2017 \\
\hline \multirow[t]{2}{*}{ Novothirtheen (catridecacog) } & \multirow[t]{2}{*}{ Yes } & \multirow[t]{2}{*}{6} & \multirow[t]{2}{*}{ PW } & $\begin{array}{l}\text { Prevention of bleeding during surgical interventions } \\
\text { in congenital factor XIII A-subunit deficiency and } \\
\text { treatment of bleeding in congenital factor XIII } \\
\text { A-subunit deficiency (birth to }<18 \text { years) }\end{array}$ & $\begin{array}{l}\text { Condition does not occur in the } \\
\text { specified paediatric subset }\end{array}$ & \multirow[t]{2}{*}{ December 2015} \\
\hline & & & & $\begin{array}{l}\text { For the prevention of bleeding in congenital } \\
\text { factor XIII A-subunit deficiency (birth to }<1 \text { year) }\end{array}$ & $\begin{array}{l}\text { No significant therapeutic } \\
\text { benefit }\end{array}$ & \\
\hline Tobi Podhaler (tobramycin) & Yes & 6 & PW & $\begin{array}{l}\text { Pseudomonas aeruginosa pulmonary } \\
\text { infection/colonisation in patients with } \\
\text { cystic fibrosis (birth to }<3 \text { months) }\end{array}$ & $\begin{array}{l}\text { Likely unsafe and no significant } \\
\text { therapeutic benefit }\end{array}$ & September 2015 \\
\hline \multirow[t]{2}{*}{$\begin{array}{l}\text { Tracleerף (bosentan } \\
\text { monohydrate) }\end{array}$} & \multirow[t]{2}{*}{ Yes } & \multirow[t]{2}{*}{3} & \multirow[t]{2}{*}{ PW } & $\begin{array}{l}\text { Systemic sclerosis and of interstitial } \\
\text { pulmonary (birth to }<18 \text { years) }\end{array}$ & $\begin{array}{l}\text { Condition does not occur in } \\
\text { the specified paediatric subset }\end{array}$ & \multirow[t]{2}{*}{ December 2013} \\
\hline & & & & $\begin{array}{l}\text { Pulmonary arterial hypertension (PAH) } \\
\text { (from } 28 \text { days to }<3 \text { months and } \\
\text { from } 12-18 \text { years) }\end{array}$ & $\begin{array}{l}\text { No significant therapeutic } \\
\text { benefit }\end{array}$ & \\
\hline
\end{tabular}


Table 2 PIP details of ODs that are authorised for use in children (Continued)

\begin{tabular}{|c|c|c|c|c|c|c|}
\hline \multirow[t]{2}{*}{ Votubia (everolimus) } & Yes & 3 & PW & $\begin{array}{l}\text { Angiomyolipoma } \\
\text { (birth to < } 18 \text { years) }\end{array}$ & $\begin{array}{l}\text { Condition does not occur } \\
\text { in the specified paediatric subset }\end{array}$ & March 2020 \\
\hline & & & & $\begin{array}{l}\text { Subependymal giant cell astrocytoma } \\
\text { and tuberous Sclerosis Complex (NA) }\end{array}$ & NA & \\
\hline \multirow[t]{2}{*}{ Vpriv (velaglucerase alfa) } & Yes & 3 & PW & $\begin{array}{l}\text { Gaucher Disease, Type } 2 \\
\text { (birth to < } 18 \text { years) }\end{array}$ & Likely ineffective & July 2015 \\
\hline & & & & $\begin{array}{l}\text { Gaucher Disease, types } 1 \text { and } 3 \\
\text { (from birth to }<24 \text { months) }\end{array}$ & $\begin{array}{l}\text { No significant therapeutic } \\
\text { benefit }\end{array}$ & \\
\hline Xagridף (anagrelide) & Yes & All & PW & $\begin{array}{l}\text { Essential Thrombocythaemiaa } \\
\text { (birth to }<6 \text { years) }\end{array}$ & $\begin{array}{l}\text { Condition does not occur in } \\
\text { the specified paediatric subset }\end{array}$ & March 2013 \\
\hline Kalydeco (ivacaftor) & Yes & 6 & $\mathrm{FP}$ & NA & NA & December 2016 \\
\hline Orfadinף & Yes & All & FP & NA & NA & May 2013 \\
\hline Revatiof & Yes & 1 & $F P$ & NA & NA & July 2014 \\
\hline
\end{tabular}

*Intended for the paediatric population at time of ODD (yes/no).

tMinimum age (in years) on SmPC at time of MA. All: age range not specified and/ or no age contraindication.

¥PIP decision granted by EMA: PW: partial waiver, FP: Full investigation plan, for the entire paediatric population. NA: Not applicable.

SExpected date of PIP completion for the remaining population.

IProduct was authorised before 2007 however the MAH applied for or had the intention to apply for an extension of the authorised indication. Consequently, pursuant to Article 8 of Regulation (EC) No 1901/2006,

the MAH submitted a PIP.

FCAS: Familial Cold Autoinflammatory Syndrome; FCU: Familial Cold Urticaria; MWS: Muckle-Wells Syndrome; NOMID: Neonatal-Onset Multisystem Inflammatory Disease; CINCA: Chronic Infantile Neurological,

Cutaneous, Articular Syndrome. 
Table 3 PIP details of potential paediatric ODs that are off-label to children

\begin{tabular}{|c|c|c|c|c|c|c|}
\hline \multirow[t]{2}{*}{ Medicine name (active substance) } & \multicolumn{2}{|c|}{ Paediatric use } & \multicolumn{4}{|c|}{ Paediatric investigation plan } \\
\hline & $\begin{array}{l}\text { Pot } \\
\text { paed* }\end{array}$ & $\begin{array}{l}\text { On } \\
\text { labelt }\end{array}$ & Decision‡ & Condition and age covered by waiver & Ground for waiver & $\begin{array}{l}\text { Expected date of } \\
\text { completion }\end{array}$ \\
\hline Signifor (pasireotide diaspartate) & Yes & No & PSW & $\begin{array}{l}\text { Pituitary dependent Cushing, overproduction } \\
\text { of pituitary ACTH, pituitary dependant } \\
\text { hyperadrenocorticism and the treatment } \\
\text { of acromegaly and pituitary gigantism } \\
\text { (birth to }<18 \text { y) }\end{array}$ & No significant therapeutic benefit & Not applicable \\
\hline Vyndaqel (Tafamidis) & Yes & No & PSW & Neuropathic heredofamilial (birth to $<18$ y) & No significant therapeutic benefit & Not applicable \\
\hline Adcetris (brentuximab vedotin) & Yes & No & PW & $\begin{array}{l}\text { Hodgkin (birth to }<5 \text { y); Anaplastic large cell } \\
\text { lymphoma (birth to }<2 y \text { ) }\end{array}$ & $\begin{array}{l}\text { Both conditions do not occur in } \\
\text { the specified paediatric subset }\end{array}$ & December 2018 \\
\hline Bronchitol (mannitol) & Yes & No & PW & $\begin{array}{l}\text { Cystic Fibrosis with pulmonary disease } \\
\text { (birth to <6y) }\end{array}$ & No significant therapeutic benefit & April 2011 \\
\hline \multirow[t]{2}{*}{ Cayston (aztreonam lysine) } & Yes & No & PW & $\begin{array}{l}\text { Treatment of gram-negative endobronchial } \\
\text { infection in bronchiectasis patients } \\
\text { (birth to }<18 \text { y) }\end{array}$ & No significant therapeutic benefit & October 2016 \\
\hline & & & & $\begin{array}{l}\text { Treatment of Pseudomonas aeruginosa } \\
\text { (PA) pulmonary infection/colonisation } \\
\text { in patients with cystic fibrosis (CF) } \\
\text { (birth to }<3 \text { months) }\end{array}$ & No significant therapeutic benefit & \\
\hline Dacogen (decitabine) & Yes & No & PW & Acute myeloid leukaemia (birth to $<28$ days) & No significant therapeutic benefit & July 2021 \\
\hline \multirow[t]{2}{*}{ Firazyr (icatibant) } & Yes & No & PW & $\begin{array}{l}\text { ACE inhibitor-induced angioedema } \\
\text { (birth to }<18 \text { ) }\end{array}$ & No significant therapeutic benefit & December 2017 \\
\hline & & & & Hereditary angioedema (birth to $<2$ years & No significant therapeutic benefit & \\
\hline Glybera (alipogene tiparvovec) & Yes & No & PW & Hyperchylomicronaemia (birth to $<2$ years) & Likely unsafe & December 2021 \\
\hline \multirow[t]{2}{*}{ Iclusig (ponatinib) } & Yes & No & PW & Chronic myeloid leukaemia (birth to $<1 \mathrm{y}$ ) & $\begin{array}{l}\text { Condition does not occur in the } \\
\text { specified paediatric subset }\end{array}$ & December 2020 \\
\hline & & & & $\begin{array}{l}\text { Acute lymphoblastic leukaemia } \\
\text { (birth to }<1 \text { y) }\end{array}$ & No significant therapeutic benefit & \\
\hline \multirow[t]{2}{*}{ Nplate (romiplostim) } & Yes & No & PW & $\begin{array}{l}\text { Disease-related thrombocytopenia in } \\
\text { myelodysplastic syndrome } \\
\text { (birth to }<18 \text { years) }\end{array}$ & Likely unsafe & December 2014 \\
\hline & & & & $\begin{array}{l}\text { Immune thrombocytopenia } \\
\text { (birth to }<1 \mathrm{y} \text { ) }\end{array}$ & No significant therapeutic benefit & \\
\hline Plenadren (hydrocortisone) & Yes & No & PW & $\begin{array}{l}\text { Adrenocortical Insufficiency } \\
(6 \text { years to }<18 \mathrm{y})\end{array}$ & No significant therapeutic benefit & October 2016 \\
\hline Revestive (Teduglutide) & Yes & No & PW & $\begin{array}{l}\text { Short bowel syndrome } \\
\text { (birth to }<4 \text { months) }\end{array}$ & No significant therapeutic benefit & February 2017 \\
\hline Revolade (eltrombopag olamine) & Yes & No & PW & $\begin{array}{l}\text { Idiopathic Thrombocytopenia Purpura } \\
\text { (birth to }<1 \text { y) Secondary } \\
\text { thrombocytopenia: NA }\end{array}$ & $\begin{array}{l}\text { Condition does not occur in the specified } \\
\text { paediatric subset }\end{array}$ & December 2019 \\
\hline
\end{tabular}


Table 3 PIP details of potential paediatric ODs that are off-label to children (Continued)

Soliris (eculizumab)

Yes

PW

Paroxysmal Nocturnal Haemoglobinuria

(PNH) (birth to $<2$ y)

STEC-HUS patients: NA AHUS: NA

Sprycel§ (Dasatinib)

Yes

No

PW

Philadelphia chromosome (BCR-ABL

translocation)-positive chronic myeloid

leukaemia (0-1y) and Philadelphia

chromosome (BCR-ABL translocation)-positive

acute lymphoblastic leukaemia (0-1y)

Sutent§

Yes

PW

Gastro-intestinal stromal tumour (0-6y)

NexoBrid (concentrate of proteolytic enzymes Yes

No

NA

Condition does not occur in the specified paediatric subset

Condition does not occur in the specified

June 2019

paediatric subset

panditions do not occur in the specified

paediatric subset

Condition does not occur in the specified_June 2018

paediatric subset

Intended for the paediatric population at time of ODD.

Paediatric use specified on SmPC at time of MA (yes/no).

PIP decision granted by EMA: CW: Class Waiver, PSW: product specific waiver W: full waiver in all subsets of the paediatric population, PW: partial waiver, FP: Full investigation plan, for the entire paediatric population. NA: Not applicable.

\$Product was authorised before 2007, however the MAH applied or had the intention to apply for an extension of the authorised indication. Consequently, pursuant to Article 8 of Regulation (EC) No 1901/2006, the MAH submitted a PIP. FCAS: Familial Cold Autoinflammatory Syndrome; FCU: Familial Cold Urticaria; MWS: Muckle-Wells Syndrome; NOMID: Neonatal-Onset Multisystem Inflammatory Disease; CINCA: Chronic Infantile Neurological, Cutaneous, Articular Syndrome. STEC-HUS: Shiga-Toxin Producing Escherichia Coli Haemolytic Uremic Syndrome; AHUS: Atypical Haemolytic Uraemic Syndrome. 
Table 4 Waiver conditions of 'adults only' OD

\begin{tabular}{|c|c|c|c|c|c|c|}
\hline \multirow{2}{*}{$\begin{array}{l}\text { Medicine name (active } \\
\text { substance) }\end{array}$} & \multicolumn{2}{|c|}{ Paediatric use } & \multicolumn{4}{|c|}{ Paediatric investigation plan } \\
\hline & $\begin{array}{l}\text { Potential } \\
\text { paediatric }^{*}\end{array}$ & $\begin{array}{l}\text { On } \\
\text { label }^{\dagger}\end{array}$ & Decision‡ & Condition and age covered by waiver & Ground for waiver & $\begin{array}{l}\text { Expected date of completion PIP for } \\
\text { remaining population }\end{array}$ \\
\hline Arzerra (ofatumumab) & No & No & CW & Chronic lymphocytic leukaemia (birth to <18y) & Class waiver & NA \\
\hline Imnovid (pomalidomide) & No & No & CW & Multiple myeloma (birth to <18y) & Class waiver & NA \\
\hline Jakavi (ruxolitinib) & No & No & CW & Myeolofibrosis (birth to <18y) & Class waiver & NA \\
\hline $\begin{array}{l}\text { Thalidomide Celgene } \\
\text { (thalidomide) }\end{array}$ & No & No & CW & Multiple myeloma (birth to <18y) & Class waiver & NA \\
\hline Afinitor (everolimus) & No & No & PSW & $\begin{array}{l}\text { Renal cell carcinoma and pancreatic neuroendocrine } \\
\text { tumour (birth to }<18 y \text { ) }\end{array}$ & $\begin{array}{l}\text { Condition occurs only in } \\
\text { adult populations }\end{array}$ & NA \\
\hline Esbriet (pirfenidone) & No & No & PSW & Idiopathic Pulmonary Fibrosis (birth to <18y) & $\begin{array}{l}\text { Condition occurs only in } \\
\text { adult populations }\end{array}$ & NA \\
\hline Nexavar ${ }^{\S}$ (Sorafenib) & No & No & PSW & Differentiated thyroid cancer (birth to <18y) & $\begin{array}{l}\text { No significant therapeutic } \\
\text { benefit over existing treatments } \\
\text { for paediatric patients. }\end{array}$ & NA \\
\hline Revlimid (lenalidomide) & No & No & PSW & $\begin{array}{l}\text { Multiple myeloma and myelodysplastic syndromes (birth } \\
\text { to }<18 \mathrm{y} \text { ) }\end{array}$ & Likely unsafe & NA \\
\hline Torisel (temsirolimus) & No & No & PSW & $\begin{array}{l}\text { For the treatment of mantle-cell lymphoma for all sub- } \\
\text { sets of the paediatric }\end{array}$ & $\begin{array}{l}\text { Condition occurs only } \\
\text { in adult populations }\end{array}$ & NA \\
\hline Bosulif (bosutinib) & No & No & PW & Chronic myeloid leukaemia (birth to $<10$ y) & $\begin{array}{l}\text { Condition occurs only } \\
\text { in adult populations }\end{array}$ & December 2016 \\
\hline Tasigna (Nilotinib) & No & No & PW & $\begin{array}{l}\text { Gastro-intestinal stromal tumour (0-18y) and chronic } \\
\text { myeloid leukaemia (0-1y) }\end{array}$ & $\begin{array}{l}\text { No significant therapeutic } \\
\text { benefit }\end{array}$ & September 2015 \\
\hline Volibris (ambrisentan) & No & No & PW & Pulmonary arterial hypertension (0-1y) & Likely unsafe & December 2016 \\
\hline
\end{tabular}

"Intended for the paediatric population at time of ODD (yes/no)

tPaediatric use specified on SmPC at time of MA.

${ }^{\mp}$ PIP decision granted by EMA: CW: Class Waiver, PSW: product specific waiver; PW: partial waiver; NA: Not applicable.

${ }^{5}$ Product was authorised before 2007, however the MAH applied or had the intention to apply for an extension of the authorised indication. Consequently, pursuant to Article 8 of Regulation (EC) No 1901/2006, the MAH submitted a PIP. 
Most of these (30/34) were granted a partial waiver, the remaining four products were required to develop and assess treatment for the complete paediatric population. None of the PIPs were completed at the time of application for MA as some of the requirements in the PIP were deferred. Partial waivers were mostly granted based on the expectation that clinical studies would be of no significant therapeutic benefit or fulfil no therapeutic need of the paediatric population. PIP decisions, waiver conditions and expected date of PIP completion are described in Tables 2, 3 and 4.

Half of the 34 products with a PIP were required to either develop an age-appropriate formulation or to assess the acceptability of the existing formulation (Table 5). The majority of these measures applied to oral formulations $(\mathrm{n}=13)$. An age-appropriate diluted formulation was required for intravenous $(\mathrm{n}=1)$ and subcutaneous $(\mathrm{n}=2)$ formulations.

For 15 products non-clinical studies had to be performed. The required measures mostly included juvenile animal studies to determine pharmacokinetics, tolerability, toxicology and/ or toxicokinetics. In some cases, specific pharmacology, exploratory or dose ranging studies were required in vitro or in other animal models.

All 34 products with a PIP required at least one clinical study in children (median $=3$, range 1-9 studies). A quarter $(\mathrm{n}=25)$ of the studies were randomised double-blind, placebo controlled studies in the target population. Another 20 studies were open label comparative trials and were either dose-comparative or using an active comparator, historical controls or standard care as controls. The majority of studies were, however, uncontrolled or observational "all-in-one" trials gathering as much data as possible in the target paediatric population, including efficacy, safety, tolerability, activity and/or pharmacokinetics (Table 5).

To date, only one orphan medicinal product completed its PIP (Glivec ${ }^{\circledR}$ ), all other PIPs are still on-going. For four products the therapeutic indication has been extended to the paediatric population $[15,16]$. On average, it takes seven years before PIPs are expected to be completed.

\section{Time course to marketing authorisation}

Figure 2 illustrates the ODDs and MAs per year. The Paediatric Drug Regulation did not significantly increase the number of ODDs with potential paediatric indications $\left(250 / 428\right.$ versus $420 / 660$ of ODDs, $x^{2}=2.78, p=$ 0.1 ) and did not lead to more MAs for ODs for children $\left(18 / 30\right.$ vs $22 / 51$ of MAs, $\left.\chi^{2}=1.53, p=0.22\right)$. Table 6 summarises the indication, age range and authorisation details of MAs for use in the paediatric population.

The final model to analyse the time between ODD and MA as survival time included after/before 2007 and age group (child/ adult) as categorical variables. The results show that after the implementation of the Paediatric Drug Regulation in 2007, drug-indication-age combinations, have a longer time to authorisation than before January 2007 (Hazard ratio (95\% CI) 2.804 (1.837-4.280), $\mathrm{p}<0.001$, Figure 3A). The same effect was observed when multiple indications of one drug were grouped (data not shown). Potential paediatric use did not prolong the overall drug development process compared to 'adults only' medicinal products (Hazard ratio (95\% CI) 1.140 (0.767-1.696), $\mathrm{p}=0.52$, Figure 3B).

The mean $(95 \% \mathrm{CI})$ time to authorisation for paediatric medicinal products after and before 2007 was 4.04 (3.02-5.07) and 2.93 (1.93-3.92). The mean (95\% CI) time to authorisation for adults-only products after and before 2007 was $4.45(3.78-5.12)$ and 2.07 (1.52-2.63) years.

Repurposing does not provide any benefit in shortening the authorisation process for neither paediatric nor adult ODs ( $\mathrm{p}=0.21$, GLM, data not shown).

\section{Discussion}

More than 80 ODs, covering nearly 100 indications, were authorised in Europe since 2000. Half of these products are available for (a subgroup of) children. Another 34 authorised ODs are currently undergoing further investigations in children. The introduction of the Paediatric Drug Regulation was associated with a longer time to MA for OD, did not significantly increase the number of ODDs with potential paediatric indications and did not lead to more MAs for paediatric indications.

In this study we were able to quantify the time to authorisation and the number of paediatric ODs, but could not extract the quality of research conducted in children given the relatively young EU Paediatric Drug Regulation. The use of Cox regression to analyse time to MA as a survival function is appropriate and the data set is large enough to draw valid conclusions. There is some autocorrelation between indications for children and adults within the same drug. This means that the time to MA for a paediatric indication is linked to that for adult indications of the same drug, because, in part, they share study results. The data set illustrates that ODs often obtain MA for adults first, for which clinical studies are easier to conduct, and later for children. A control group would have been desirable, but since non-ODs do not have the same starting point (time of obtaining ODD), comparison in this context is not possible and data would have to be based on different criteria which is beyond the scope of this study.

Administrative processes are not static, they change over time, and that also applies to the approval of ODs. This implies that the time to MA, modelled as survival time in our Cox regression model, may not be completely independent of time. This time dependency was 
Table 5 Studies agreed upon in the PIPs of ODs

\begin{tabular}{ll}
\hline Measure & N \\
\hline Quality & 14 \\
- Development of age appropriate formulation & 2 \\
- Assessment of acceptability/ palatability & 1 \\
- Bioequivalence & 2 \\
- Microbiological testing & $\mathbf{1 9}$ \\
Total & \\
Non-clinical & 20 \\
- Juvenile toxicity study & 8 \\
- Other & $\mathbf{2 8}$ \\
Total & \\
Clinical & 1 \\
- Meta-analysis & 25 \\
- Randomised, double blind, placebo controlled & 20 \\
- Comparative, open label & 41 \\
- Uncontrolled & 3 \\
- Observational & $\mathbf{1 0 4}$ \\
- Bioequivalence/ bioavailability & 5 \\
- (PB)PK & 2 \\
- Pooled data & 3 \\
- Extrapolation & 3 \\
- Other & 1 \\
\hline
\end{tabular}

addressed by using after/before 2007 as a separate categorical variable. Since the granted therapeutic indication at the time of MA is the result of the assessment of the quality, safety and efficacy data submitted with the marketing application, this may be different (narrower) to the indications proposed at the time of ODD application [17]. After 2007, the Paediatric Committee (PDCO) safeguards that for any potential paediatric medicinal product an investigation plan is made.

The situation for patients with rare diseases has, without a doubt, improved dramatically after 2000, the year in which the EU Orphan Drug Regulation was implemented. Before 2000 only eight products, so called orphan-like drugs, were authorised for the treatment of rare diseases with the support of the EMA [18]. Four of these orphan-like drugs were authorised for use in children. In contrast, the United States introduced the Orphan Drug Act almost 20 years earlier, in 1983 [19]. Over the period 2000-2009, 148 (13\%) of 1138 ODDs received MA in the U.S., of which $81 \%$ were potentially beneficial for children [20]. In the same period in the EU only 55 of 703 of ODDs were authorised and only $52 \%$ of the products were authorised in children.

The Paediatric Drug Regulation, implemented to increase the availability of effective and safe drugs of good quality for children, was also beneficial for ODs. The majority of ODs with potential paediatric use that were off label to children at the time of MA ( $40 \%$ of all ODs) is currently in development for the paediatric population. Also, $40 \%$ of ODs authorised for children are undergoing further investigations to either expand the intended treatment group to include younger children

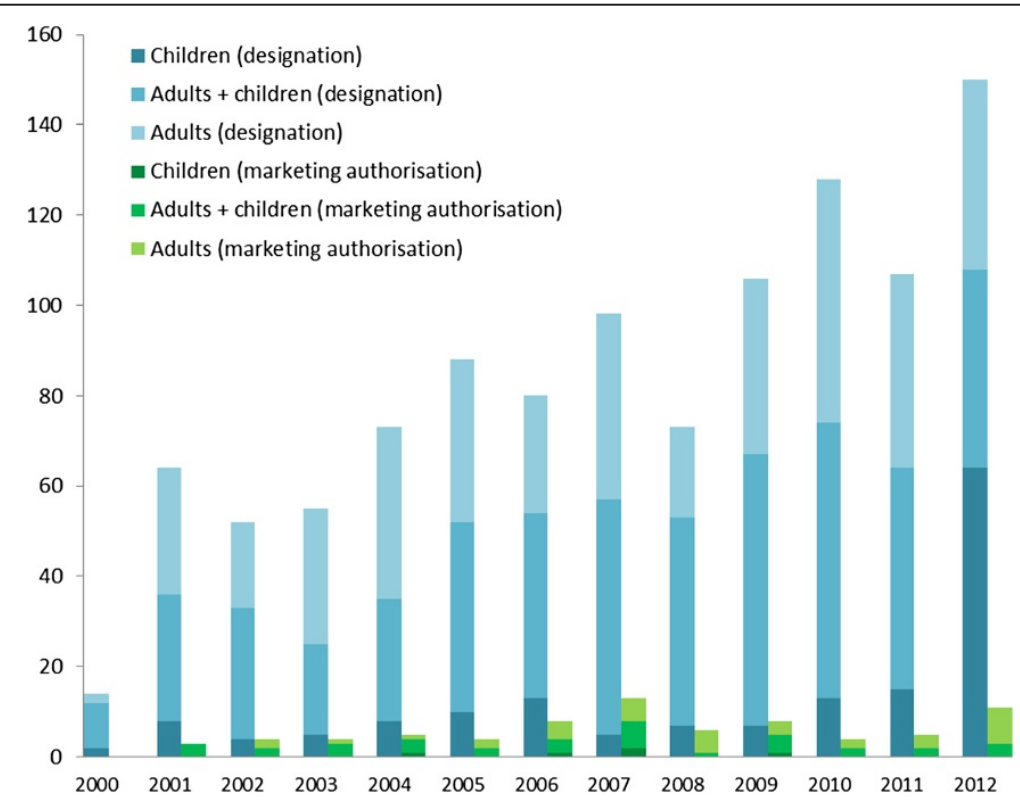

Figure $\mathbf{2}$ New orphan drug designation and marketing authorisations per year and age category. 
Table 6 All ODs with MA for the paediatric population

\begin{tabular}{|c|c|c|c|c|c|}
\hline Medicine name & Active substance & Indication & Age range & Authorisation date & Status \\
\hline Fabrazyme & Agalsidase beta & Fabry disease (galactosidase-A deficiency) & 8 years and older & 03/08/2001 & End of marketing exclusivity \\
\hline Replagal & Agalsidase alpha & Fabry disease (galactosidase-A deficiency) & 7 years and older & 03/08/2001 & $\begin{array}{l}\text { Authorised under exceptional } \\
\text { circumstance, end of } \\
\text { marketing exclusivity }\end{array}$ \\
\hline Glivec & Imatinib & Chronic myeloid leukaemia & $>1$ and $>2$ years & $07 / 11 / 2001$ & Withdrawn OD status \\
\hline Tracleer & Bosentan monohydrate & Pulmonary arterial hypertension (PAH) & 2 years and older & 15/05/2002 & Authorised \\
\hline Zavesca & Miglustat & Niemann-Pick type-C disease & Children* and adults & 20/11/2002 & Authorised \\
\hline \multirow[t]{4}{*}{ Carbaglu } & \multirow[t]{4}{*}{ Carglumic acid } & $\begin{array}{l}\text { Hyperammonaemia due to - N-acetylglutamate-synthase } \\
\text { (NAGS) primary deficiency }\end{array}$ & \multirow[t]{4}{*}{ As early as the first day of life } & \multirow[t]{4}{*}{$24 / 01 / 2003$} & \multirow[t]{4}{*}{$\begin{array}{l}\text { Authorised, end of marketing } \\
\text { exclusivity for NAGS }\end{array}$} \\
\hline & & - isovaleric acidaemia & & & \\
\hline & & - methymalonic acidaemia & & & \\
\hline & & - propionic acidaemia & & & \\
\hline Aldurazyme & Laronidase & Mucopolysaccharidosis I (alpha-L-iduronidase deficiency) & Children* and adults & 10/06/2003 & $\begin{array}{l}\text { Authorised under exceptional } \\
\text { circumstance, end of } \\
\text { marketing exclusivity }\end{array}$ \\
\hline Busilvex & Busulfan & $\begin{array}{l}\text { Conditioning treatment prior to conventional } \\
\text { haematopoietic progenitor cell transplantation (HPCT) }\end{array}$ & Newborn and older & 09/07/2003 & End of marketing exclusivity \\
\hline Lysodren & Mitotane & Advanced adrenal cortical carcinoma & Children** and adults & $28 / 04 / 2004$ & Authorised \\
\hline Pedea & Ibuprofen & Patent ductus arteriosus & Premature newborns & $29 / 07 / 2004$ & Authorised \\
\hline Wilzin & Zinc & Wilson's disease & One year and older & $13 / 10 / 2004$ & Authorised \\
\hline Xagrid & Anagrelide & Essential thrombocythaemia & Children** and adults & $16 / 11 / 2004$ & $\begin{array}{l}\text { Authorised under exceptional } \\
\text { circumstances }\end{array}$ \\
\hline Orfadin & Nitisinone & Hereditary tyrosinaemia type 1 (HT-1) & Children* and adults & $21 / 02 / 2005$ & Authorised \\
\hline Revatio & Sildenafil & Pulmonary arterial hypertension & one year and older & 28/10/2005 & Authorised \\
\hline Naglazyme & Galsulfase & $\begin{array}{l}\text { Mucopolysaccharidosis VI (N-acetylgalactosamine-4-sulfatase } \\
\text { deficiency; Maroteaux-Lamy syndrome) }\end{array}$ & Children* and adults & 24/01/2006 & $\begin{array}{l}\text { Authorised under exceptional } \\
\text { circumstances }\end{array}$ \\
\hline Myozyme & Alglucosidase alpha & Pompe disease (acid-a-glucosidase deficiency) & Children of all ages and adults & 29/03/2006 & Authorised \\
\hline Evoltra & Clofarabine & Acute lymphoblastic leukaemia & $1-21$ years & 29/05/2006 & $\begin{array}{l}\text { Authorised under exceptional } \\
\text { circumstances }\end{array}$ \\
\hline Exjade & Deferasirox & Beta thalassaemia major with iron overload & 2 years and older & $28 / 08 / 2006$ & Authorised \\
\hline Diacomit & Stiripentol & $\begin{array}{l}\text { Severe myoclonic epilepsy in infancy } \\
\text { (SMEl, Dravet's syndrome) }\end{array}$ & 3 years and older & 04/01/2007 & Conditional approval \\
\hline Elaprase & Idursulfase & Hunter syndrome (mucopolysaccharidosis II) & 5 years and older & 08/01/2007 & $\begin{array}{l}\text { Authorised under exceptional } \\
\text { circumstances }\end{array}$ \\
\hline
\end{tabular}


Table 6 All ODs with MA for the paediatric population (Continued)

\begin{tabular}{|c|c|c|c|c|c|}
\hline Inovelon & Rufinamide & Lennox-Gastaut syndrome & 4 years and older & 16/01/2007 & Authorised \\
\hline Cystadane & Betaine anhydrous & Homocystinuria & Children* and adults & $15 / 02 / 2007$ & Authorised \\
\hline Soliris & Eculizumab & $\begin{array}{l}\text { Paroxysmal nocturnal haemoglobinuria (PNH) } \\
\text { and atypical haemolytic uremic syndrome (aHUS) }\end{array}$ & Children* and adults & 20/06/2007 & Authorised \\
\hline Siklos & Hydroxycarbamide & Sickle-cell syndrome & 2 years and older & 29/06/2007 & Authorised \\
\hline Increlex & Mecasermin & $\begin{array}{l}\text { Primary insulin-like-growth-factor-1 deficiency } \\
\text { (primary IGFD) }\end{array}$ & 2 to 18 years & 03/08/2007 & $\begin{array}{l}\text { Authorised under exceptional } \\
\text { circumstances }\end{array}$ \\
\hline Atriance & Nelarabine & $\begin{array}{l}\text { Acute lymphoblastic leukaemia (T-ALL) and T-cell } \\
\text { lymphoblastic lymphoma (T-LBL) }\end{array}$ & Children* and adults & $22 / 08 / 2007$ & $\begin{array}{l}\text { Authorised under exceptional } \\
\text { circumstances }\end{array}$ \\
\hline Kuvan & Sapropterin dihydrochloride & $\begin{array}{l}\text { Phenylketonuria (PKU) and tetrahydrobiopterin } \\
\text { (BH4) deficiency }\end{array}$ & 4 years and older & $02 / 12 / 2008$ & Authorised \\
\hline Mepact & Mifamurtide & Osteosarcoma & 2 to 30 years & 06/03/2009 & Authorised \\
\hline Peyona & Caffeine citrate & Primary apnoea & Premature newborns & $02 / 07 / 2009$ & Authorised \\
\hline Mozobil & Plerixafor & Lymphoma and multiple myeloma & Children** and adults & $31 / 07 / 2009$ & Authorised \\
\hline Cayston & Aztreonam lysine & Cystic fibrosis (CF) & 6 years and older & $21 / 09 / 2009$ & Authorised \\
\hline Ilaris & Canakinumab & $\begin{array}{l}\text { Cryopyrin-Associated Periodic Syndromes (CAPS), } \\
\text { and Systemic Juvenile Idiopathic Arthritis (SJIA) }\end{array}$ & 2 years and older & 23/10/2009 & $\begin{array}{l}\text { Authorised under exceptional } \\
\text { circumstances, withdrawn } \\
\text { OD status }\end{array}$ \\
\hline Tepadina & Thiotepa & $\begin{array}{l}\text { Allogeneic or autologous haematopoietic progenitor } \\
\text { cell transplantation (HPCT) }\end{array}$ & Children* and adults & $15 / 03 / 2010$ & Authorised \\
\hline Vpriv & Velaglucerase alpha & Type-1 Gaucher disease & $>2$ years & $26 / 08 / 2010$ & Authorised \\
\hline Tobi Podhaler & Tobramycin & Cystic fibrosis & 6 years and older & 20/07/2011 & Authorised \\
\hline Votubia & Everolimus & $\begin{array}{l}\text { Subependymal giant-cell astrocytoma (SEGA) } \\
\text { associated with tuberous-sclerosis complex (TSC) }\end{array}$ & 3 years and older & 02/09/2011 & Conditional approval \\
\hline Xaluprine & 6-Mercaptopurine monohydrate & Acute lymphoblastic leukaemia (ALL) & Children* and adults & 09/03/2012 & Authorised \\
\hline Kalydeco & Ivacaftor & $\begin{array}{l}\text { Cystic fibrosis (CF) with G551D mutation in the } \\
\text { CFTR gene }\end{array}$ & 6 years and older & 23/07/2012 & Authorised \\
\hline Novothirteen & Catridecacog & Congenital factor-XIII-A-subunit deficiency & 6 years and above & 03/09/2012 & Withdrawn OD status \\
\hline Procysbi & Mercaptamine bitartrate & Nephropathic cystinosis & Children* and adults & 06/09/2013 & Authorised \\
\hline Orphacol & Cholic acid & $\begin{array}{l}\text { Inborn errors in primary bile-acid synthesis } \\
\text { due to 3-hydroxy-5-C27-steroid oxidoreductase } \\
\text { deficiency or 4-3-oxosteroid-5-reductase deficiency }\end{array}$ & One month and older & $12 / 09 / 2013$ & $\begin{array}{l}\text { Authorised under exceptional } \\
\text { circumstances }\end{array}$ \\
\hline Defitelio & Defibrotide & $\begin{array}{l}\text { Severe hepatic veno-occlusive disease (VOD) in } \\
\text { haematopoietic stem-cell transplantation (HSCT) therapy }\end{array}$ & One month and older & 18/10/2013 & $\begin{array}{l}\text { Authorised under exceptional } \\
\text { circumstances }\end{array}$ \\
\hline
\end{tabular}

*Age range not specified in SmPC.

**Not contraindicated in children, however the SmPC mentions a special warning (such as "The effects of medicinal product on children and adolescents have not been studied" or "limited information on the use in children"). 


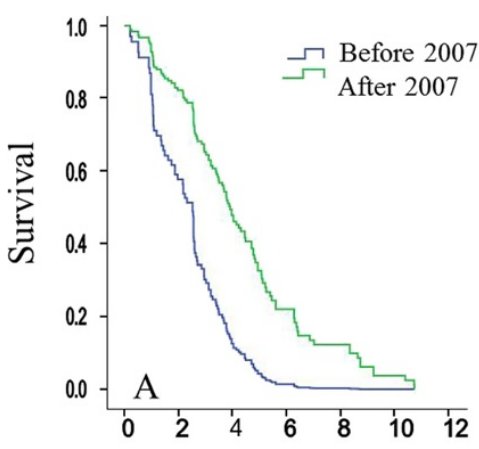

Follow up time (years)

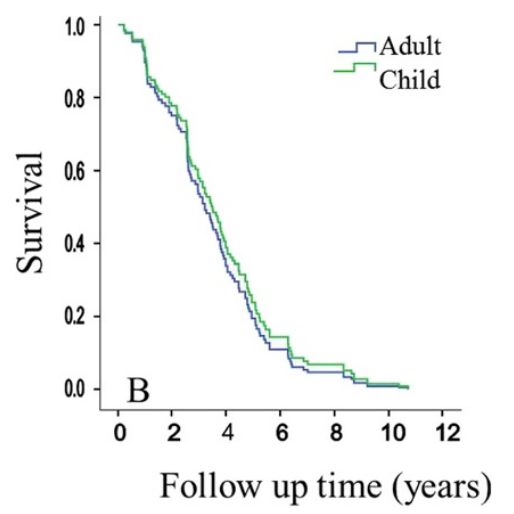

Figure 3 Cox regression survival curve as a function of (A) 2007 (after/ before) and (B) age group (child/ adult).

and/or to develop an age appropriate formulation for youngsters. This would presumably not have taken place without the instalment of the Paediatric Drug Regulation.

A drawback is the high number of deferrals for both ordinary and orphan products. In deferrals, either initiation or completion of paediatric studies is postponed until the medicinal product is authorised for use in adults, to ensure that it is safe to do research in children and that availability for adults is not delayed.

In the 5 year progress report on the paediatric regulation, the EMA concluded that authorisation of medicines for adults was not delayed. However, in our analysis, products authorised before 2007 had a shorter time to MA than those authorised after the Paediatric Drug Regulation came into force. Apparently the Paediatric Drug Regulation added complexity to the R\&D and regulatory process of orphan medicinal products, exemplified by the applicants' investments time and effort in drafting a PIP.

Others also expressed concern that the EU Paediatric Drug Regulation retards drug development and authorisation for adults by demanding paediatric trials, especially for rare diseases [21,22]. It is not only the Paediatric Drug Regulation that causes delay. There are potential other product- and company-related factors such as the indication for which a drug is being developed, the type of drug product in development, the company's experience in developing $\mathrm{OD}$ and the size of the companies submitting the MA application [23-25], and incentives such as those for Small and Medium Sized companies implemented in December 2005 [26]. Other economic and bureaucratic issues such as the increasing amount of regulations where applicants have to comply with during drug development in general have their effects. However, the increased approval time after 2007 can also be an artefact, caused by the submission of ODD applications increasingly earlier in the developmental phase.

Given the relatively young EU Paediatric Drug Regulation, there are few data on PIP completion and outcome in rare diseases, especially since deferrals lead to an additional seven years before expected completion of the files for paediatric indications. So far, only one product successfully reached completion of development. Furthermore, no orphan-designated medicine has yet obtained the orphan incentive of two additional years of market exclusivity. The impact of introducing PIPs will become apparent in the next few years when more PIPs are expected to be completed and will learn whether applicants are compliant with measures and timelines agreed upon in PIPs.

We could not demonstrate that repurposing is an effective strategy for the development of drugs for rare diseases in children. Drug repurposing is considered an interesting acceleration and facilitation of OD development at lower cost and with lower risk of failure, since these drugs have already been studied [7]. Although repurposed drugs have already been studied in animals and/or humans to some extent, a positive benefit/risk balance has to be established for the intended paediatric population. Since research in children on average takes another seven years after safety and efficacy have been confirmed in adults, this is considered to be the ratelimiting step, irrespective of repurposing.

There is a need for novel research tools to support decisions that balance between exposing children to experiments and the obvious need to provide children with authorised good quality drugs. Comparative trials are considered the primary instrument to collect the evidence needed for MA. However, for rare disease this is often not feasible. In most cases, the studies requested in the PIPs were open label uncontrolled studies. Most studies were designed to collect as much data as possible, ranging from pharmacokinetics and dose finding to safety and efficacy. When experimental research is not feasible, on-going data collection through registry/ observational programs (such as named patient programmes (NPP) or compassionate use) are in place to characterise both long-term safety and efficacy as well as 
to determine patient characteristics and disease progression $[27,28]$. There are differences in implementation of legislation throughout the EU. For example, the French authorities explicitly mention that investigation is not the goal of an NPP and that an NPP may not replace a clinical trial [29].

Several novel research strategies have been proposed, such as meta-analytic approaches, extrapolation, modelling and simulation. With the use of sparse sampling, population pharmacokinetics/pharmacodynamics (POP-PK/PD) and/or physiologically based pharmacokinetic models, extrapolation from adults to children, interpolation between paediatric age subgroups and the optimal use of scientific literature and in vitro/preclinical data, drug development is enriched while minimising the burden of studies in children [30]. Since the implementation of the Paediatric Drug Regulation, especially simulation and modelling are increasingly used for paediatric drug development [15].

Non-clinical juvenile studies are often used to bridge the knowledge gap between mature and immature systems, to detect safety issues early and to predict the dose in children. A recent survey showed that in the majority of juvenile toxicity studies, findings were comparable to those for adults, yielding no new information [31]. Furthermore, novel toxicity was uncommon and could have been predicted from either known pharmacology or from adult data. On the other hand, in a preliminary review of 5 completed juvenile animal studies required in PIPs, unexpected organ toxicity and increased sensitivity was observed in 3 medicinal products, stressing the importance of conduction juvenile animal studies [15]. It confirms that drug development is not a "one size fits all" process. A case-by-case evaluation process is necessary, especially for paediatric ODs.

Part of paediatric drug development is to avoid duplication and to ensure that ongoing and planned paediatric research is transparent. To this purpose, in March 2011, the EU Clinical Trials Register (EU-CTR) was made publicly accessible (EU-CTR) for paediatric trials included in a PIP [15]. The website (available at https:// www.clinicaltrialsregister.eu) provides public access to information extracted from the EU clinical trials database (EudraCT), such as protocols and known results. The clinical trials included are those with agreed PIPs from investigator sites within and outside the European Economic Area (EEA). As soon as a paediatric trial is approved, it becomes accessible in the database.

\section{Conclusions}

The EU Paediatric Drug Regulation did not increase the number of ODDs with potential paediatric indications nor did it lead to more MAs for paediatric indications. It was associated with a longer time to MA for both adult and paediatric orphan indications. Nonetheless, the Paediatric
Drug Regulation has ensured the further paediatric development of drugs still off-label to children. The impact on the quality and volume of research in the paediatric population through PIPs will become clear in the coming few years. Case-by-case assessment, based on innovative research tools is necessary to collate the best evidence while protecting children from unnecessary experiments.

\section{Abbreviations}

CW: Class waiver; EEA: European economic area; EMA: European medicines agency; EPAR: European public assessment report; EU: European union; EU-CTR: EU clinical trials register; EudraCT: EU clinical trials database; FDA: US food and drug administration; FP: Full PIP for the entire paediatric population; GLM: General linear model; MA: Marketing authorisation; NA: Not applicable; NPP: Named patient programme; OD: Orphan drug; ODD: Orphan drug designation; PDCO: Paediatric committee; PIP: Paediatric investigational plan; POP-PK/PD: Population pharmacokinetics/pharmacodynamics;

PSW: Product specific waiver; PUMA: Paediatric use marketing authorisation; PW: Partial waiver; SmPC: Summary of product characteristics; W: Full waiver in all subsets of the paediatric population.

\section{Competing interests}

ACE Pharmaceuticals BV specialises in medical need products and orphan drugs. The authors declare that they have no competing interests.

\section{Authors' contributions}

ARKV and PJdV designed the study, collected data and performed analysis and interpretation of the data. RvdV and $A d B$ were involved in writing and revising the manuscript. All the authors read and approved the final manuscript.

\section{Author details}

'Utrecht Institute for Pharmaceutical Sciences, Division of Pharmacoepidemiology and Clinical Pharmacology, Utrecht University, P.O. Box 80 082, 3508 TB Utrecht, The Netherlands. ${ }^{2}$ ACE Pharmaceuticals BV, Schepenveld 41, 3891 ZK Zeewolde, The Netherlands. ${ }^{3}$ Department of Internal Medicine, Tergooi Hospital, Van Riebeeckweg 212, 1213 XZ Hilversum, the Netherlands.

Received: 16 May 2014 Accepted: 21 July 2014

Published: 5 August 2014

\section{References}

1. European Parliament: Regulation (EC) No. 1901/2006 of the European Parliament and of the Council of 12 December 2006 on medicinal products for paediatric use and amending Regulation (EEC) No 1768/92, Directive 2001/20/EC, Directive 2001/83/EC and Regulation (EC) No 726/ 2004. Off J Eur Communities 2006, 2006(L378):1-19.

2. van Weely S, Leufkens HGM: Background paper on orphan diseases for the WHO Report on Priority Medicines for Europe and the World, October 2004. In Priority medicines for Europe and the World - a public health approach to innovation. Edited by Kaplan W, Laing R. Geneva: World Health Organization; 2004.

3. Institute of Medicine (US) Committee on Accelerating Rare Diseases Research and Orphan Product Development: Rare Diseases and Orphan Products: Accelerating Research and Development. Washington (DC): National Academies Press (US); 2010.

4. Orphanet: "Rare Diseases: understanding this Public Health Priority". Available at: [http://www.eurordis.org/sites/default/files/publications/ princeps_document-EN.pdf]

5. De Vrueh R, Baekelandt ERF, de Haan JMH: Update on 2004 Rare Disease Background Paper Written by S. van Weely, Ph.D. and Prof. H.G.M. Leufkens. Available at: [www.who.int/medicines/areas/priority_medicines/ BP6_19Rare.pdf]

6. European Parliament: Regulation (EC) No. 141/2000 of the European Parliament and of the Council of 16 december 1999 on Orphan Medicinal Products. Off J Eur Communities 2000, 43(L18):1-5.

7. Sardana D, Zhu C, Zhang M, Gudivada RC, Yang L, Jegga AG: Drug repositioning for orphan diseases. Brief Bioinform 2011, 12:346-356. 
8. Murteira S, Millier A, Ghezaiel Z, Lamure M: Drug reformulations and repositioning in the pharmaceutical industry and their impact on market access: regulatory implications. J Market Access Health Policy 2014, 2:22813.

9. Xu K, Cote TR: Database identifies FDA-approved drugs with potential to be repurposed for treatment of orphan diseases. Brief Bioinform 2011, 12:341-345.

10. Norman P: Repurposing as a strategy for orphan drug development, evidence from European approvals. Expert Opin Orphan Drugs 2013, 1:473-480.

11. Muthyala R: Orphan/rare drug discovery through drug repositioning Drug Discov Today: Ther Strat 2011, 8:71-76.

12. Rocchi F, Tomasi P: The development of medicines for children. Part of a series on Pediatric Pharmacology, guest edited by Gianvincenzo Zuccotti, Emilio Clementi, and Massimo Molteni. Pharmacol Res 2011, 64:169-175.

13. Conroy S, Choonara I, Impicciatore P, Mohn A, Arnell H, Rane A, Knoeppel C, Seyberth H, Pandolfini C, Raffaelli MP, Rocchi F, Bonati M, Jong G, de HM, van den Anker J: Survey of unlicensed and off label drug use in paediatric wards in European countries. European Network for Drug Investigation in Children. BMJ 2000, 320:79-82.

14. Eurordis: Paediatric drugs and rare diseases. Available at: [http://www. eurordis.org/en/content/paediatric-drugs-and-rare-diseases]

15. European Medicines Agency: 5-year Report to the European Commission. General report on the experience acquired as a result of the application of the Paediatric Regulation (EMEA/428172/2012). Available at: [http://ec. europa.eu/health/files/paediatrics/2012-09_pediatric_report-annex1-2_en.pdf]

16. European Medicines Agency: Cayston-EMEA/H/C/000996/II/0018: Variation Assessment Report. Available at: [http://www.ema.europa.eu/docs/en_GB/ document_library/EPAR_-_Assessment_Report_-_Variation/human/000996/ WC500132159.pdf]

17. European Medicines Agency: Guideline on the format and content of applications for designation as orphan medicinal products and on the transfer of designations from one sponsor to another, 9 July 2007. ENTR/ 6283/00 Rev 3. Available at: [http://ec.europa.eu/health/files/orphanmp/ doc/2007_07/format_content_orphan_applications_rev3_200707_en.pdf]

18. Ceci A, Felisi M, Baiardi P, Bonifazi F, Catapano M, Giaquinto C, Nicolosi A, Sturkenboom M, Neubert A, Wong I: Medicines for children licensed by the European Medicines Agency (EMEA): the balance after 10 years. Eur $\lrcorner$ Clin Pharmacol 2006, 62:947-952.

19. United States Food and Drug Administration: Orphan Drug Act. Pub L 1983, 97-414:Stat.2049.

20. Thorat C, Xu K, Freeman SN, Bonnel RA, Joseph F, Phillips MI, Imoisili MA: What the Orphan Drug Act has done lately for children with rare diseases: a 10-year analysis. Pediatrics 2012, 129:516-521.

21. Peyvandi F, Rosendaal FR, O'Mahony B, Mannuccio MP: Pediatric requirements in Europe stymie help for hemophilia. Nat Med 2014, 20:117.

22. Rose K: European Union pediatric legislation jeopardizes worldwide, timely future advances in the care of children with cancer. Clin Ther 2014, 36:163-177.

23. Heemstra HE, Leufkens HG, Rodgers RP, Xu K, Voordouw BC, Braun MM: Characteristics of orphan drug applications that fail to achieve marketing approval in the USA. Drug Discov Today 2011, 16:73-80

24. Heemstra HE, de Vrueh RL, van WS, Buller HA, Leufkens HG: Predictors of orphan drug approval in the European Union. Eur J Clin Pharmacol 2008, 64:545-552.

25. Putzeist M, Heemstra HE, Garcia JL, Mantel-Teeuwisse AK, Gispen-De Wied CC, Hoes AW, Leufkens HG: Determinants for successful marketing authorisation of orphan medicinal products in the EU. Drug Discov Today 2012, 17:352-358.

26. European Medicines Agency: User guide for micro, small and mediumsized enterprises (SMEs) on the administrative and procedural aspects of the provisions, laid down in Regulation (EC) No 726/2004, that are of particular relevance to SMEs. EMA/860940/2011. Available at: [http:// www.ema.europa.eu/docs/en_GB/document_library/Regulatory_ and_procedural_guideline/2009/10/WC500004134.pdf]

27. Groft SC: Rare diseases research: expanding collaborative translational research opportunities. Chest 2013, 144:16-23.

28. Tilson H, Primatesta P, Kim D, Rauer B, Hawkins PN, Hoffman HM, KuemmerleDeschner J, van der Poll T, Walker UA: Methodological challenges in monitoring new treatments for rare diseases: lessons from the cryopyrin-associated periodic syndrome registry. Orphanet J Rare Dis 2013, 8:139.

29. Kreeftmeijer-Vegter AR, van Veldhuizen CK, de Vries PJ: Roll out of intraveneous artesunate under named patient programmes in the Netherlands, Belgium and France. Orphanet J Rare Dis 2013, 8:150.

30. Manolis E, Osman TE, Herold R, Koenig F, Tomasi P, Vamvakas S, Saint-Raymond A: Role of modeling and simulation in pediatric investigation plans. Paediatr Anaesth 2011, 21:214-221.

31. Bailey GP, Marien D: The value of juvenile animal studies "What have we learned from preclinical juvenile toxicity studies? II". Birth Defects Res $B$ Dev Reprod Toxicol 2011, 92:273-291.

doi:10.1186/s13023-014-0120-x

Cite this article as: Kreeftmeijer-Vegter et al: The influence of the European paediatric regulation on marketing authorisation of orphan drugs for children. Orphanet Journal of Rare Diseases 2014 9:120.

\section{Submit your next manuscript to BioMed Central and take full advantage of:}

- Convenient online submission

- Thorough peer review

- No space constraints or color figure charges

- Immediate publication on acceptance

- Inclusion in PubMed, CAS, Scopus and Google Scholar

- Research which is freely available for redistribution 